\title{
MOTIVASI WANITA BEKERJA DAN PENGARUHNYA TERHADAP KONTRIBUSI PENDAPATAN WANITA DALAM MEMBANTU PENDAPATANKELUARGA DI KECAMATANMARPOYAN DAMAIKOTA PEKANBARU
}

\author{
Yessi Nesneri dan Virna Museliza \\ Fakultas Ekonomi dan Ilmu Sosial UIN Suska Riau \\ Email:yessinesneri@yahoo.com
}

\begin{abstract}
Currently women, not only serves as a housewife who serves her husband, children, and all members of her family, but many women have other jobs besides housework. Some women no longer be the primary educators for children the next generation, because they have to do quite time consuming job outside the home. As a result, many emerging daycare to address the problem of child care that his/her mother worked. This was triggered by the emancipation of women and the social and economic demands of the household is quite heavy encourage women to earn a living to supplement the family income in order to achieve the welfare of the family.

This study aims to determine the factors that motivate women to work and to find out how much revenue contribution of women to the family income. To achieve these objectives, the research done by using three (3) independent variables, namely Women's income (X1), Working Time Allocation (X2), and Total Dependent in the Family (X3). Analysis of the data used in this research is descriptive and quantitative analysis, using the tool SPSS windows version 22, with multiple linear regression analysis, F test (Test Simultaneous), $t$ test (Partial Test), and the Determination Test (R2). The result shows that the two independent variables (Women's Income, and Total Dependents in the familyhave significant effect on the dependent variable (Contributions of Women in Family Income (Y)). While the Working Time Allocation variable does not have significant influenceto Contributions of Women in Family Income $(Y)$. in addition, there is a contribution of independent variables (independent) on the dependent variable (dependent) amounted to $60.3 \%$, while the remaining $39.7 \%$ is influenced by other variables not examined in this study.
\end{abstract}

Keywords: Women, Women's income, Working Time Allocation, Total Dependent in the Family

\footnotetext{
Abstrak:Dewasa ini kenyataan menunjukkan bahwa wanita pada zaman sekarang, tidak hanya berperan sebagai ibu rumah tangga yang melayani suami, anak, seluruh anggota keluarganya. Serta bukan lagi menjadi pendidik utama bagi anak-anak generasi penerus bangsa yang dibuktikan dengan banyaknya tempat penitipan anak, kewajiban yang seharusnya dijalankan oleh seorang wanita dititipkan pada orang lain. hal ini dipicu oleh adanya emansipasi wanitadan tuntutan sosial serta ekonomi rumah tangga yang cukup berat mendorong wanita mencari nafkah untuk menambah penghasilan keluarga demi tercapainya kesejahteraan keluarga.Penelitian ini bertujuan untuk mengetahui faktor -faktor apa saja yang menjadi motivasi wanita bekerja dan untuk mengetahui seberapa besar kontribusi pendapatan wanita untuk pendapatan keluarga. Untuk mencapai tujuan tersebut maka dilakukan penelitian dengan menggunakan 3 (tiga) variabel independen yaitu Pendapatan Wanita $\left(X_{1}\right)$, Alokasi Waktu Bekerja $\left(\mathrm{X}_{2}\right)$, dan Jumlah Tanggungan Keluarga $\left(\mathrm{X}_{3}\right)$. Analisis data yang di gunakan pada penelitian ini adalah analisis deskriptif dan kuantitatif, yakni dengan menggunakan alat bantu program SPSS windows versi 22. Yaitu untuk melakukan analisis Regresi Linear Berganda, Uji F (Uji Simultan), Uji t (Uji
} 
Yessi Nesneri dan Virna Museliza: Motivasi Wanita Bekerja \& Pengaruhnya terhadap Kontribusi Pendapatan Wanita dalam Membantu Pendapatan Keluarga di Kecamatan Marpoyan Damai Kota Pekanbaru

Parsial), dan Uji Determinasi $\left(R^{2}\right)$. Berdasarkan hasil analisis yang telah dilakukan didapat bahwa, kedua variabel independen (Pendapatan Wanita, dan Jumlah Tanggungan Keluarga berpengaruh signifikan terhadap variabel dependen (Kontribusi Pendapatan Wanita Untuk Pendapatan Keluarga (Y)). Sedangkan Variabel Alokasi Waktu Bekerja tidak berpengaruh signifikan terhadap Kontribusi Pendapatan Wanita Untuk Pendapatan Keluarga (Y).Selain itu, terdapat sumbangan pengaruh variabel bebas (independen) terhadap variabel terikat (dependen) adalah sebesar 60,3 \%, sedangkan sisanya sebesar 39,7 \% dipengaruhi oleh variabel lain yang tidak diteliti dalam penelitian ini.

Kata Kunci: wanita, pendapatan wanita, alokasi waktu bekerja, jumlah tanggungan keluarga dan pendapatan keluarga

\section{PENDAHULUAN}

Indonesia merupakan salah satu negara yang memiliki penduduk terbanyak di dunia, yakni berada di peringkat 4 dengan jumlah penduduk mencapai 253.609.643 jiwa. ${ }^{1}$ Jumlah penduduk yang besar dan berkualitas tentu menjadi impian setiap bangsa sebagai salah satu modal dasar pembangunan.

Pembangunan dapat dikatakan berhasil jika keluarga sejahtera di mana tingkat pendapatan per kapita masyarakat meningkat dan mampu menaikkan tingkat hidup serta menghilangkan kemiskinan, sebab apabila keluarga sejahtera maka masyarakat akan mengutamakan bagaimana memperbaiki kualitas diri seperti tingkat pendidikan, keterampilan dan kesehatan. Dalam Undang-undang Nomor 10 Tahun 1992 tentang Perkembangan Kependudukan dan Pembangunan Keluarga Sejahtera denganjelas disebutkan, bahwa Keluarga Sejahtera adalah keluarga yang dibentuk berdasarkan atas perkawinan yang sah, mampu memenuhi kebutuhan hidup spiritual, material yang layak, bertakwa kepada Tuhan Yang Maha Esa, memiliki hubungan yang serasi, selaras, dan seimbang antar anggota dan antar keluarga dengan masyarakat dan lingkungan.

Peran dan Partisipasi seluruh masyarakat Indonesia tanpa memandang dari golongan manapun sangatlah dibutuhkan demi kelancaran pembangunan termasuk di dalamnya wanita, wanita merupakan salah satu sumber daya manusia di pasar kerja terutama Indonesia, partisipasi wanita dalam dunia kerja memberikankontribusi yang besar terhadap kesejahteraan keluarga sebab wanita yang bekerja akan menambah penghasilan keluarga yang secara otomatis mampu meningkatkan kualitas gizi dan kesehatan seluruh anggota keluarga yang pada akhirnya akan memberikan kontribusi besar dalam mensukseskan pembangunan.

Kedudukan dan peran wanita untuk pembangunan semakin kuat dengan dimasukkannya peranan wanita dalam Tap MPR No.IV/MPR/ 1999 dalam GBHN yang berbunyi 
sebagai berikut: Pertama; Meningkatkan kedudukan dan peranan perempuan dalam kehidupan berbangsa dan bernegara melalui kebijaksanaan nasional yang diemban oleh lembaga yang mampu memperjuangkan terwujudnya kesetaraan dan keadilan gender. Kedua; Meningkatkan kualitas peran dan kemandirian organisasi perempuan dengan tetap mempertahankan nilai pemerataan dan kesatuan serta nilai historis perjuangan kaum perempuan dalam rangka melanjutkan usaha pemberdayaan perempuan serta kesejahteraan keluarga dan masyarakat.

Pada dasarnya peranan wanita yang utama adalah menciptakan rumah tangga yang berkualitas yakni dalam rumah tangga, wanita atau isteri harus bertanggung jawab untuk memberikan semua pelayanan kepada anak-anak, suami, dan anggota - anggota keluarga lainnya sepanjang hidupnya.Wanita siap tidak tidur demi kebahagiaan suami dan anak-anaknya, serta mengorbankan tenaga untuk kebahagiaan keluarga dan kelanggengan hidupnya. Selain itu wanita juga sangat berperan dalam proses pendidikan dan perkembangan anak sebagai generasi penerus bangsa.

Wanita adalah guru pertama bagi sang anak, sebelum dididik orang lain. Sejak ruh ditiupkan ke dalam rahim, proses pendidikan sudah dimulai. Sebab mulai saat itu, anak telah mampu menangkap rangsangan-rangsangan yang dberikan oleh ibunya. anak mampu mendengar dan merasakan apa yang dirasakan ibunya. Bila ibunya sedih dan cemas, anak pun merasakan demikian. Sebaliknya, bila ibunya merasa senang, anak pun turut senang. Dalam Islam, wanita harus berperan sebagai pendidik umat, yakni menanamkan pendidikan akidah, pendidikan ibadah dan pendidikan akhlak sedini mungkin, sehingga anak meyakini bahwa kita hidup tidak semau kita. Tapi di sana ada pengatur, pengawas tujuan hidup, akhir dari kehidupan. Kemudian meyakini bahwa apa yang terjadi pada kita, pasti akan kembali pada sang khalik. Selanjutnya wanita berperan sebagai pendamping suami dalam sebuah artikel yang ditulis oleh Ummu Muhammad mengatakan bahwasuami yang shaleh kebanyakan dibelakangnya ada isteri shalehah. ${ }^{2}$ Akan tetapi Islam tidak melarang wanita untuk bekerja serta malakukan kegiatan dalam perekonomian selama pekerjaannya itu tidak mengenyamping kan keluarga, hal ini terdapat dalam surah An-Nisa ayat 32 yang artinya "(Karena) laki-laki memiliki bagian dari apa yang mereka usahakan, dan para wanita (pun) memiliki bagian dariapa yang mereka usahakan, dan mohonlah kepada Allah sebagian dari karunia-Nya, Sesungguhnya Allah Maha Mengetahui segala sesuatu." Ayat ini selain menjelaskan tentang hak kepemilikan bagi kaum wanita, juga menetapkan tentang 
Yessi Nesneri dan Virna Museliza: Motivasi Wanita Bekerja \& Pengaruhnya terhadap Kontribusi Pendapatan Wanita dalam Membantu Pendapatan Keluarga di Kecamatan Marpoyan Damai Kota Pekanbaru

kobolehan wanita bekerja karena pada ayat ini, yang diasumsikan adalah kehalalan apa yang diusahakan, yaitu mencari penghasilan. Selain itu juga diungkapkan tentang kepemilikan penghasilan dan pendapatan yang diperoleh.

Jumlah wanita di duniasaat inihampir seimbang dengan jumlah laki-laki. Bila potensi ini tidak diarahkan dan dididik dengan baik, wanita akan menjadi penghancur masyarakat, negara bahkan dunia. Suatu masyarakat dikatakan berhasil, bila wanitanya berakhlak mulia. Wanita bagaikan mahkota, bila mahkota baik, maka seluruhnya akan kelihatan cantik dan bagus. Tapi bila mahkotanya rusak, maka yang lainpun tidak ada artinya apa-apa. Seorang wanita tidaklah cukup berkutat dalam rumah saja sebagai Ibu Rumah Tangga karena para tunas bangsa dan agama telah menunggu uluran tangannya. Apalagi pada saat ini, umat sedang mengalami penurunan akidah, moral dan ibadah.

Dewasa ini kenyataan menunjukkan bahwa wanita pada zaman sekarang, tidak hanya berperan sebagai ibu rumah tangga yang melayani suami, anak, seluruh anggota keluarganya dan masyarakat. Serta bukanlagi menjadi pendidik utama bagi anak-anak generasi penerus bangsa yang dibuktikan dengan banyaknya tempat penitipan anak, kewajiban yang seharusnya dijalankan oleh seorang wanita dititipkan pada orang lain. hal ini dipicu oleh adanya emansipasi wanitadan tuntutan sosial serta ekonomi rumah tangga yang cukup berat mendorong wanita mencari nafkah untuk menambah penghasilan keluarga demi tercapainya kesejahteraan keluarga.

Terdapat beberapa faktor yang memotivasi wanita untuk bekerja yaitu suami tidak bekerja, pendapatan rumah tangga yang rendah, sedangkan jumlah tanggungan keluarga yang cukup tinggi, mengisi waktu luang, ingin mencari uang sendiri, dan ingin mencari pengalaman. ${ }^{3}$

Meningkatnyajumlah anakyang dimiliki, maka meningkat pula beban tanggungan keluarga tersebut. Hal ini didukung oleh simanjuntak yang mengatakan bahwajumlah tanggungan yang tinggi pada suatu rumah tangga tanpa diikuti dengan peningkatan dari segi ekonomi akan mengharuskan anggota keluarga selain kepala keluarga untuk mencari nafkah. ${ }^{4}$

Keperluan akan peningkatan ekonomi rumah tangga merupakan salah satu alasan utama para wanita meninggalkan peran mereka yang pada awalnya hanya sebagai ibu rumah tangga akhirnya masuk ke pasar kerja.Masuknya angkatan kerja wanita ke berbagai sektor menandakan bahwa tidak ada batasan untuk bekerja bagi wanita. Banyak lapangan pekerjaan yang dulunya hanya dikerjakan oleh 
kaum lelaki sekarang sudah bisa dikerjakan oleh kaum wanita. Perubahan yang terjadi sekarang ini sebagai akibat dari perubahan lingkungan ekonomi sosial.

Keterlibatan wanita di lapangan kerja sering kali menimbulkan kontroversi.Pertama berkaitan dengan perbedaan persepsi tentang fungsi wanita. Tidak sedikit masyarakat yang berpendapat bahwa fungsi wanita adalah sebagai ibu rumah tangga/ ibunya anak-anak, yang berperan mengurus semua keperluan anak dan memberikan pendidikan dini kepada anak baik akidah, akhlak, maupun tentang sains dan tekhnologi yang nantinya akan berpengaruh kepada kemajuan suatu bangsa dan negara. Hal ini tentunya selaras dengan sabda Rasulullah SAW yang mengatakan bahwa : "wanita adalah tiang negara, jika wanitanya baik maka baiklah negaranya, dan apabila wanita rusak, maka hancurlah negaranya" (HR.Muslim). Selain sebagai ibu rumah tangga / ibunya anak-anak wanita juga berperan sebagai sebagai isteri sekaligus pendamping suami yang senantiasa mengingatkan suami dalam bertindak / cerdas memberikan motivasi-motivasi yang positif kepada suami, mampu memberikan ketenangan dan kesejukan bagi suami, senantiasa taat kepada perintah suami, serta memberikan pelayanan terbaik kepada suami, dengan kata lain wanita adalah penyejuk hati suami dikala hatinya kacau, gelisah, gundah gulana, pengayom dan penentram jiwa anak, penentu di balik kegagahan dan keperkasaan suami, penginspirasi sekaligus motivator di balik kesuksesan suami dan rumah tangga.

Kedua, berkaitan dengan hakhak wanita dalam dunia kerja. Pekerja wanita sering dipandang berada pada posisi yang sangat istimewa, bila dibandingkan dengan laki-laki.Secara kodrat wanita memiliki siklus menstruasi, hamil, melahirkan dan menyusui sedangkan laki-laki tidak, ketika wanita merasa nyeri karena haid sesuai dengan UU No. 13 Tahun 2003 pasal 81 maka wanita tidak diwajibkan bekerja di hari pertama dan kedua, selanjutnya pasal 82 menyebutkan bahwa pekerja wanita berhak atas istirahat selama 1,5 bulan sebelum dan 1,5 bulan sesudah melahirkan atau sesuai dengan surat keterangan dokter. Ketika pekerja wanita masih dalam masa menyusui, sesuai dengan bunyi pasal 83, mereka berhak atas waktu untuk menyusui anaknya.Bahkan, saat cuti melahirkan dan haid pun, sesuai Undang-Undang pekerja wanita berhak mendapatkan gaji dan jaminan kesehatan. Akan tetapi untuk tunjangan lainnya di atur menurut ketentuan tempat bekerja. Hal ini mengindikasikan bahwa rata-rata pendapatan wanita tidak akan lebih besar di bandingkan dengan laki-laki. 
Yessi Nesneri dan Virna Museliza: Motivasi Wanita Bekerja \& Pengaruhnya terhadap Kontribusi Pendapatan Wanita dalam Membantu Pendapatan Keluarga di Kecamatan Marpoyan Damai Kota Pekanbaru

Pendapatan wanita bekerja merupakan bagian yang tidak terpisahkan dari bagian pendapatan keluarga. Hasil kerja yang didapat dan berapapun hasil yang dibawa pulang oleh wanita bekerja semuanya digunakan untuk mencukupi kebutuhan rumah tangga dan keluarganya. Hal ini menunjukkan bahwa isteri atau wanita yang bekerja membantu suami mencari nafkah mengabdi secara total kepada keluarga dan rumah tangganya, dengan mengesampingkan kebutuhan dirinya sendiri.

Motif dan tujuan dalam bekerja akan berbeda antara pria dan wanita. Bagi pria, bekerja merupakan kewajiban yang harus dijalankan karena tanggung jawabnya sebagai kepala keluarga dan pencari nafkah.Sedangkan bagi wanita, khususnya yang berstatus menikah, bekerja dapat diartikan untuk membantu perekonomian keluarga karena penghasilan suami belum mencukupi hal ini terjadi pada wanita yang mempunyai suami yang memiliki pendidikan rendah serta tidak mempunyai keterampilan. Para wanita dalam kasus ini tidak akan memperdulikan pekerjaan apa yang mereka kerjakan, yang terpenting bagi mereka adalah mendapatkan pendapatan tambahan agar kebutuhan dapat terpenuhi.Untuk wanita yang mampu/ kaya, bekerja berarti dapat berfungsi sebagai pengisi waktu atau menunjukkan identitas diri, mengaplikasikan ilmu pengetahuan, menginginkan adanya kebebasan finansial untuk mengikuti gaya hidup masyarakat. Bagi wanita merasa keterlibatannya didalam bekerja mempunyai arti tersendiri. Yakni sebagai individu, isteri, ibu rumah tangga dan anggota masyarakat. Semakin tinggi tingkat partisipasi angkatan kerja wanita sering dianggap sebagai indikasi adanya transformasi ekonomi.

Dalam kondisi perekonomian yang berkembang saat ini, harga barang kebutuhan pokok tidak stabil, yang secara langsung akan berpengaruh kepada semakin besarnya biaya hidup untuk memenuhi kebutuhan keluarga.Untuk bisa memenuhi kebutuhan keluarga tersebutjika hanya mengandalkan satu sumber penghasilan saja, tentunya akan timbul banyak kesulitan. Untuk itulah maka sebagian wanita memutuskan untuk ikut membantu perekonomian keluarga dengan ikut bekerja.Dengan ikut bekerja berarti wanita ikut pula menopang ekonomi keluarga.Namun tetap diharapkan wanita tidak melupakan kodratnya sebagai wanita dan ibu rumah tangga. Berdasarkan latar belakang masalah tersebut maka permasalahan dapat dirumuskan sebagai berikut :"faktor apa sajakah yang menjadi motivasi wanita bekerja dan seberapa besar kontribusi pendapatan wanita bekerja untuk pendapatan keluarga?". Penelitian ini bertujuan untuk mengetahui faktor - 
faktor apa saja yang menjadi motivasi wanita bekerja dan untuk mengetahui seberapa besar kontribusi pendapatan wanita untuk pendapatan keluarga".

\section{TINJAUAN PUSTAKA}

\section{Tenaga Kerja dan Angkatan Kerja}

Menurut Undang-undang No. 13 Tahun 2003 tentang Ketenagakerjaan Pasal 1, tenaga kerja adalah setiap orang yang mampu melaksanakan pekerjaan baik didalam maupun diluar hubungan kerja guna menghasilkan barang dan jasa untuk memenuhi kebutuhan masyarakat.

Tenaga kerja adalah penduduk yang sudah atau sedang bekerja, sedang mencari pekerjaan dan yang melakukan kegiatan-kegiatan lain, seperti bersekolah, mengurus rumah tangga dan menerima pendapatan lain. Batas umur minimum tenaga kerja yaitu 15 tahun tanpa ada batas umur maksimum. ${ }^{5}$

Sumber utama penawaran tenaga kerja adalah penduduk. Tenaga kerja merupakan penduduk yang berada dalam usia kerja.Penduduk dipandang sebagai pemacu pembangunan. ${ }^{6} \mathrm{Hal}$ ini disebabkan adanya kegiatan produksi dengan adanya orang yang membeli dan mengkonsumsi barang-barang yang dihasilkan. Konsumsi tersebut akan menciptakan permintaan agregate, dimana hal tersebut dapat mendorong usaha-usaha produktif untuk berkembang dan meningkatkan perekonomian secara keseluruhan.
Selaras dengan Dumairy Menurut Tadaro $^{7}$ pertumbuhan penduduk bukan merupakan suatu masalah, justru merupakan unsur penting yang akan memacu pembangunan ekonomi. Sebab, populasi yang lebih besar merupakan pasar potensial yang menjadi sumber permintaan atas barang dan jasa, yang kemudian akan menggerakkan berbagai kegiatan ekonomi.

Penduduk memiliki peran ganda dalam perekonomian. Dalam konteks pasar tenaga kerja, penduduk dapat dipandang dari sisi permintaan dan penawaran. Dari sisi permintaan, penduduk adalah konsumen yang merupakan sumber permintaan akan barang dan jasa. Sedangkan dari sisi penawaran, penduduk dapat dipandang sebagai sebuah produsen.

Menurut Undang-undang Tenaga Kerja No. 13 Tahun 2003 Angkatan kerja adalah penduduk yang berusia 15-64 tahun yang sudah mempunyai pekerjaan tetapi sementara tidak bekerja, maupun yang sedang aktif mencari pekerjaan.

Berdasarkan Badan Pusat Statistik angkatan kerja yang digolongkan bekerja adalah:

1. Mereka yang selama seminggu sebelum pencacahan melakukan pekerjaan dengan maksud memperoleh atau membantu memperoleh penghasilan atau keuntungan yang lamanya bekerja 
Yessi Nesneri dan Virna Museliza: Motivasi Wanita Bekerja \& Pengaruhnya terhadap Kontribusi Pendapatan Wanita dalam Membantu Pendapatan Keluarga di Kecamatan Marpoyan Damai Kota Pekanbaru

paling sedikit satu jam dalam seminggu yang lalu ;

2. Mereka yang selama seminggu sebelum pencacahan tidak melakukan pekerjaan atau bekerja kurang dari satu jam tapi mereka adalah :

a. Pekerja tetap, pegawai-pegawai pemerintah atau swasta yang sedang tidak masuk kerja karena cuti, sakit, mogok, mangkir ataupun perusahaan menghentikan kegiatan sementara ;

b. Petani yang mengusahakan tanah pertanian yang tidak bekerja karena menunggu hujan untuk menggarap sawah ;

c. Orang-orang yang bekerja dibidang keahlian.

Berdasarkan Badan Pusat Statistik Angkatan Kerja yang digolongkan menganggur dan sedang mencari pekerjaan yaitu :

1. Mereka yang belum pernah bekerja, pada saat ini sedang berusaha mencari pekerjaan ;

2. Mereka yang sudah pernah bekerja, tapi pada saat pencacahan sedang menganggur dan berusaha mendapat pekerjaan.

\section{Pengertian Motivasi}

Motivasi (motivation) yaitu yang berkaitan dengan keinginan untuk melakukan pekerjaan. ${ }^{8}$ sedangkan Siagian mendefenisikan motivasi kerja sebagai daya dorong bagi seseorang untuk memberikan kontribusi yang sebesar-besarnya demi keberhasilan organisasi mencapai tujuannya, dengan pengertian bahwa tercapainya tujuan organisasi berarti tercapai pula tujuan pribadi para anggota organisasi yang bersangkutan. ${ }^{9}$

Motivasi kerja merupakan suatu modal dalam menggerakkan dan mengarahkan para karyawan atau pekerja agar dapat melaksanakan tugasnya masing-masing dalam mencapai sasaran dengan penuh kesadaran, kegairahan dan bertanggung jawab. Motivasi kerja dapat memberi energi yang menggerakkan segala potensi yang ada, menciptakan keinginan yang tinggi dan luhur, serta meningkatkan kebersamaan. Ada dua aspek motivasi, yaitu segi pasif dimana motivasi tampak sebagai kebutuhan dan sekaligus pendorong, dan dari segi statis dimana motivasi tampak sebagai satu usaha positif dalam menggerakkan daya dan potensi tenaga kerja agar secara produktif berhasil mencapai tujuan yang telah ditetapkan sebelumnya. ${ }^{10}$

Motivasi atau dorongan dapat digambarkan sebagai tenaga pendorong dalam diri individu yang memaksa untuk bertindak. Ada beberapa teori mengenai motivasi diantaranya yaitu:

1. Teori hierarki kebutuhan dari Abraham Maslow

Menurut maslow dalam Robbins $^{11}$, yakni orang-orang atau 
individu termotivasi untuk berperilaku dalam pekerjaannya untuk memenuhi kebutuhannya yang terdiri dari lima tingkatan kebutuhan.Kelima kebutuhan itu adalah kebutuhan fisik meliputi makanan, minuman, tempat tinggal.Kebutuhan keamanan meliputi keamanan dan perlindungan. Kebutuhan sosial meliputi perasaan diterima dan dicintai oleh orang lain. Kebutuhan akan penghargaan meliputi harga diri, pengakuan status serta kebutuhan aktualisasi diri meliputi pemahaman dan pengambangan diri.

\section{Teori Herzberg}

Menurut Herzberg dalam Siagian ${ }^{12}$, bahwa karyawan termotivasi untuk bekerja disebabkan oleh dua faktor, yaitu :

1. Faktor Intrinsik yaitu faktor daya dorong yang timbul dari dalam diri masing-masing karyawan, berupa :

a. Pekerjaan itu sendiri (the work it self), yakni berat ringannya tantangan yang dirasakan tenaga kerja dari pekerjaannya.

b. Kemajuan (advancement), yakni Besar kecilnya kemungkinan tenaga kerja berpeluang maju dalam pekerjaannya seperti naik pangkat.

c. Tanggungjawab (responsibility), yakni besar kecilnya yang dirasakan terhadap tanggung jawab diberikan kepada seorang tenaga kerja.

d. Pengakuan (recognition), yakni besar kecilnya pengakuan yang diberikan kepada tenaga kerja atas hasil kerja.

e. Pencapaian (achievement), yaknibesar kecilnya kemungkinan tenaga kerja mencapai prestasi kerja tinggi.

2. Faktor Ekstrinsik yaitu faktor pendorong yang datang dariluar diri seseorang terutama dari organisasi tempatnya bekerja. Faktor ekstrinsik ini mencakup :

a. Administrasi dan kebijakan perusahaan, yakni tingkat kesesuaian yang dirasakan tenaga kerja terhadap semua kebijakan dan peraturan yang berlaku dalam perusahaan.

b. Penyeliaan, yakni tingkat kewajaran penyelia dirasakan yang oleh tenaga kerja.

c. Gaji, yakni tingkat kewajaran gaji yang diterima sebagai imbalan terhadap tugas pekerjaan.

d. Hubungan antar pribadi, yakni tingkat kesesuaian yang dirasakan dalam berinteraksi antar tenaga kerja lain. 
e. Kondisi kerja, yakni tingkat kesesuaian kondisi kerja dengan proses pelaksanaan tugas pekerjaan-pekerjaannya.

Apabila faktor intrinsik tersebut ada, dapat memberi tingkat motivasi yang kuat dan kepuasan dalam diri seseorang, namun jika faktor ini tidak ada, maka menimbulkan rasa ketidak puasan. Sementara faktor ekstrinsik tersebut ada, tidak perlu memberi motivasi, tetapi jika tidak ada dapat menimbulkan tidak puas.

3. Teori Mc. Cleland

Teori Mc. Cleland berpendapat bahwa setiap orang mempunyai cadangan energi potensial. Bagaimana energi ini dilepaskan dan digunakan tergantung pada kekuatan dorongan motivasi seseorang dan situasi serta peluang yang tersedia. Energi akan dimanfaatkan seseorang karena adanya dorongan oleh :

1. Kekuatan motif dan kekuatan dasar yang terlibat

2. Harapan keberhasilannya, dan

3. Nilai insentif yang melekat pada tujuan yang ingin di capai oleh seseorang

\section{Motivasi Wanita Bekerja}

Terdapat beberapa faktor yang memotivasi wanita untuk bekerja yaitu suami tidak bekerja, pendapatan rumah tangga yang rendah, sedangkan jumlah tanggungan keluarga yang cukup tinggi, mengisi waktu luang, ingin mencari uang sendiri, dan ingin mencari pengalaman. ${ }^{13}$

Meningkatnyajumlah anakyang dimiliki, maka meningkat pula beban tanggungan keluarga tersebut. Hal ini didukung oleh simanjuntak ${ }^{14}$ yang mengatakan bahwa jumlah tanggungan yang tinggi pada suatu rumah tangga tanpa diikuti dengan peningkatan dari segi ekonomi akan mengharuskan anggota keluarga selain kepala keluarga untuk mencari nafkah.Selanjutnya menurut Endang, Tatik, dan Sumarlan ada beberapa hal yang menjadi motivasi wanita dalam memutuskan untuk bekerja antara lain adalah sebagai berikut:

Pertama; didorong oleh faktor ekonomi misalnya bekerja guna menambah pendapatan keluarga , dalam hal ini pendapatan keluarga terdiri dari pendapatan wanita (ibu rumah tangga), pendapatan suami, dan pendapatan lain-lain / Pendapatan total yang dihasilkan oleh suatu keluarga untuk dapat memenuhi kebutuhan sehari-hari yang dilihat dari beban / jumlah tanggungan keluarga.

kedua; didorong oleh mental spiritual misalnya bekerja untuk mempraktekkan ilmu pengetahuan dan keterampilan yang diperoleh dan ketiga; bekerja hanya untuk menghabiskan waktu senggang. Pada penelitian ini penulis mengambil teori dari Asyiek, 
dkk dalam Artini dan Handayani karena dirasakan sesuai dengan objek penelitian yakni pada kelurahan Marpoyan Damai Kota Pekanbaru banyak pekerja wanita yang tidak mempunyai pendidikan tinggi atau keterampilan. Mereka bekerja hanya untuk memenuhi kebutuhan sehari-hari agar dapat bertahan di tengah semakin bergejolaknya perekonomian.

Adapun yang memotivasi wanita dalam bekerja serta kontribusi pendapatan wanita untuk pendapatan keluarga adalah sebagai berikut:

1) Perekonomian keluarga yang rendah / pendapatan suami yang rendah, menyebabkan wanita ingin bekerja dan hasil dari kerja wanita diberikan untuk menambah pendapatan keluarga yang rendah untuk memenuhi kebutuhan hidup seharihari. Pendapatan wanita adalah salah salah satu faktor yang mempunyai pengaruh langsung terhadap kontribusi pendapatan rumah tangga, dimana pendapatan wanita (ibu rumah tangga) merupakan semua penerimaan wanita yang didapatkan dari hasilnya bekerja.

2) Mengisi waktu luang yang dapat dilihat dengan berapa banyak waktu yang dialokasikan oleh wanita untuk bekerja dalam sehari, mengingat peran dan fungsi wanita sangat banyak dalam kehidupan berumah tangga.Peningkatan jam kerja tenaga kerja wanita bertujuan untuk lebih meningkatkan pendapatan atau mendapatkan penghasilan yang lebih besar, karena semakin lama waktu dialokasikan untuk bekerja maka semakin tinggi pendapatan yang akan diterima. Akan tetapi wanita harus tetap mengetahui dan melakukan kewajibannya sebagai ibu rumah tangga, yang tentunya akan menuntut peran ganda yang optimal.

3) Motivasi wanita dalam bekerja salah satunya dipengaruhi oleh tingginya kebutuhan peningkatan ekonomi rumah tangga yang dipicu oleh tingginya jumlah tanggungan keluarga. Jumlah tanggungan keluarga merupakan banyaknya anggota rumah tangga yang tidak produktif maupun yang produktif, yang secara ekonomis menjadi tanggungan dalam keluarga, dengan satuan yang digunakan adalah orang (jiwa).

\section{Pendapatan Keluarga}

Pendapatan dalam ilmu ekonomi didefinisikan sebagai hasil berupa uang atau hal materi lainnya yang dicapai dari penggunaan kekayaan atau jasa manusia bebas. Wahyu ${ }^{15}$ berpendapat bahwa pendapatan atau income adalah uang yang diterima oleh seseorang dari perusahaan dalam bentuk gaji, upah, sewa, bunga dan laba termasuk juga beberapa tunjangan seperti kesehatan 
Yessi Nesneri dan Virna Museliza: Motivasi Wanita Bekerja \& Pengaruhnya terhadap Kontribusi Pendapatan Wanita dalam Membantu Pendapatan Keluarga di Kecamatan Marpoyan Damai Kota Pekanbaru

dan pensiun.

Selain itu, Menurut Yuliana ${ }^{16}$ pendapatan merupakan semua penerimaan seseorang sebagai balas jasanya dalam proses produksi. Balas jasa tersebut bisa berupa upah, bunga, sewa, maupun, laba tergantung pada faktor produksi pada yang dilibatkan dalam proses produksi.

Bambang Swasta Sumuharjo dalam Buku Kemiskinan dan Kebutuhan pokok yang dikutip Riana Mustika Agustin ${ }^{17}$ merinci pendapatan dalam 3 (tiga) kategori yaitu :

1. Pendapatan berupa uang yaitu segala penghasilan berupa uang yang sifatnya regular dan yang diterima biasanya sebagai balas jasa atau kontra prestasi ;

2. Pendapatan berupa barang adalah segala pendapatan yang sifatnya regular dan biasa, akan tetapi selalu berbentuk balas jasa dan diterima dalam bentuk barang dan jasa ;

3. Pendapatan yang bukan merupakan pendapatan adalah segala penerimaan yang besifat transfer redisteributive dan biasanya membuat perubahan dalam keuangan rumah tangga.

Menurut T. Gilarso ${ }^{18}$ Pendapatan keluarga merupakan balas karya atau jasa atau imbalan yang diperoleh karena sumbangan yang diberikan dalam kegiatan produksi.
Secara konkritnya pendapatan keluarga berasal dari :

1. Usaha itu sendiri: misalnya berdagang, bertani, membuka usaha sebagai wiraswastawan;

2. Bekerja pada orang lain: misalnya sebagai pegawai negeri atau karyawan;

3. Hasil dari pemilihan: misalnya tanah yang disewakan dan lain-lain.

Sedangkan pendapatan rumah tangga adalah total pendapatan dari setiap anggota rumah tangga dalam bentuk uang yang diperoleh baik sebagai gaji atau upah usaha rumah tangga atau sumber lain. Kondisi seseorang dapat diukur dengan menggunakan konsep pendapatan yang menunjukkan jumlah seluruh uang yang diterima oleh seseorang atau rumah tangga selama jangka waktu tertentu. ${ }^{19}$

\section{Hipotesis Penelitian}

Berdasarkan latar belakang masalah dan tinjauan pustaka yang telah diuraikan diatas, maka dapat diajukan hipotesis sebagai berikut:

1. Didugamotivasi wanita bekerja adalah karena pendapatan keluarga yang rendah / membantu suami untuk meningkatkan pendapatan keluarga, jumlah tanggungan keluarga yang cukup tinggidanuntuk mengisi waktu luang. 
2. Di duga pendapatan wanita bekerja mempunyai kontribusi yang berarti dalam meningkatkan pendapatan keluarga.

\section{METODE PENELITIAN}

Dalam melakukan penelitian ini, penulis mengambil objek penelitian pada Kecamatan Marpoyan Damai Kota Pekanbaru Provinsi Riau. Pemilihan lokasi di kecamatan Marpoyan Damai berdasarkan alasan bahwa di kecamatan Marpoyan Damai tersebut banyak terdapat wanita yang berstatus ibu rumah tangga yang bekerja, serta pertimbangan adanya kesediaan pihak instansi, khususnya wanita yang bekerja dan berdomisili di Kecamatan Marpoyan Damai Kota Pekanbaru untuk memberikan informasi. Hal ini memungkinkan untuk mendapatkan data yang akurat sehingga lebih mendukung analisa yang sesuai dengan kondisi sesungguhnya.

Untuk melaksanakan penelitian ini, maka penulis akan menggunakan data untuk analisis sebagai berikut :

a. Data primer, yaitu data yang diperoleh langsung dari obyek penelitian, berupa hasil wawancara dan pengamatan secara langsung kepada wanita yang berstatus ibu rumah tangga yang bekerja yang terpilih sebagai sampel. Data ini adalah sumber data utama penelitian yang akan dilakukan.

b. Data sekunder adalah data yang tidak diusahakan sendiri oleh peneliti. Data ini diambil dengan tujuan untuk melengkapi informasi yang akan disajikan pada laporan penelitian. Data diperoleh dari arsip atau dokumen dan literatur-literatur yang ada yang terkait dengan tema penelitian, baik berupa buku yang memuat teori-teori, hasil penelitian terdahulu, serta pencatatan datadata yang telah ada di instansi.

Data yang dipergunakan dalam penelitian ini dikumpulkan dengan cara: 1. Metode wawancara, yaitu dengan mengadakan wawancara langsung dengan responden. Wawancara bertujuan untuk memperoleh data mengenai karakteristik responden yang meliputi umur responden, tingkat pendidikan responden, pekerjaan responden, lamanya masa kerja responden, jarak rumah responden dengan tempat kerja, motivasi wanita bekerja, pekerjaan suami, pendapatan suami, pendapatan wanita, alokasi waktu bekerja, dan jumlah tanggungan keluarga. Metode ini menggunakan daftar pertanyaan yang telah disiapkan terlebih dahulu.

2. Metode observasi, yaitu dengan mengadakan pengamatan dan pencatatan secara langsung kepada obyek penelitian yakni wanita (ibuibu rumah tangga) yang bekerja yang berdomisili di kecamatan 
Yessi Nesneri dan Virna Museliza: Motivasi Wanita Bekerja \& Pengaruhnya terhadap Kontribusi Pendapatan Wanita dalam Membantu Pendapatan Keluarga di Kecamatan Marpoyan Damai Kota Pekanbaru

Marpoyan Damai.

Populasi adalah wilayah generalisasi yang terdiri atas obyek/ subyek yang mempunyai kualitas \& karakteristik tertentu yang ditetapkan oleh peneliti untuk dipelajari dan kemudian ditarik kesimpulannya. ${ }^{20}$

Populasi dalam penelitian ini adalah penduduk di Kecamatan Marpoyan Damai Kota Pekanbaru yang berjumlah 137.658 jiwa dengan jumlah penduduk masing-masing kelurahan adalah sebagai berikut:

Tabel 1: Luas, Jumlah Penduduk dan Kepadatan Penduduk di Kecamatan Marpoyan Damai Tahun 2013

\begin{tabular}{|c|l|c|c|c|}
\hline No & \multicolumn{1}{|c|}{ Kelurahan } & Luas (KM $\mathbf{K M}^{\mathbf{2}}$ & $\begin{array}{c}\text { Jumlah } \\
\text { Penduduk }\end{array}$ & $\begin{array}{c}\text { Kepadatan } \\
\left.\text { (Jiwa/ KM } \mathbf{~ M}^{2}\right)\end{array}$ \\
\hline 1 & Tangkerang Tengah & 4,64 & 35.901 & 7.737 \\
\hline 2 & Tangkerang Barat & 5,35 & 19.14 & 3.578 \\
\hline 3 & Maharatu & 11,26 & 33.503 & 2.975 \\
\hline 4 & Sidomulyo Timur & 7,19 & 27.696 & 3.852 \\
\hline 5 & Wonorejo & 1,34 & 21.418 & 15.984 \\
\hline \multicolumn{2}{|c|}{ Jumlah } & $\mathbf{2 9 , 7 8}$ & $\mathbf{1 3 7 . 6 5 8}$ & $\mathbf{4 . 6 2 2}$ \\
\hline
\end{tabular}

Sumber : Kantor Camat Marpoyan Damai, 2014

Sampel adalah bagian dari jumlah dan karakteristik yang dimiliki oleh populasi tersebut.

Untuk pengambilan sampel secara pasti belum ada keseragaman dari para ahli statistik, akan tetapi penulis menggunakan Metode SlovinUntuk menentukan ukuran sampel dengan penentuan sampel sebagai berikut:

$$
n=\frac{N}{1+N e^{2}}
$$

Di mana :

$\mathrm{n}=$ ukuran sampel

$\mathrm{N}=$ ukuran populasi

$. !=$ persen kelonggaran ketidaktelitian karena kesalahan pengambilan sampel yang masih dapat ditolerir atau diinginkan, misalnya $10 \%$.

Sehingga didapat sampelnya sebagai berikut:

$n=\frac{137.658}{1+137.658(10)^{2}}=99,93$ atau 100

Maka sampel penelitian adalah 100 orang. ${ }^{21}$

Dari perhitungan Slovin di atas, dapat diketahui jumlah responden yang akan digunakan dalam penelitian ini adalah sebanyak 100 orang. Selanjutnya akan diterapkan proporsional sampling, yaitu pengambilan subjek 
atau sampel pada setiap wilayah dengan seimbang atau sebanding dengan banyaknya subjek atau sampel dalam masing-masing wilayah. ${ }^{22}$ Perhitungan tersebut secara rinci dapat dilihat dalam tabel 2 berikut ini:

Tabel 2 : Proporsi Responden Penelitian

\begin{tabular}{|c|l|r|r|r|c|}
\hline No & \multicolumn{1}{|c|}{ Kelurahan } & \multicolumn{1}{c|}{$\begin{array}{c}\text { Jumlah } \\
\text { Populasi }\end{array}$} & $\begin{array}{c}\text { Proporsi } \\
\mathbf{( \% )}\end{array}$ & $\begin{array}{c}\text { Sampel } \\
\text { Penelitian }\end{array}$ & $\begin{array}{c}\text { Jumlah } \\
\text { Sampel }\end{array}$ \\
\hline 1 & Tangkerang Tengah & 35.901 & 26 & $26 \% \times 100$ & 26 \\
\hline 2 & Tangkerang Barat & 19.14 & 14 & $14 \% \times 100$ & 14 \\
\hline 3 & Maharatu & 33.503 & 24 & $24 \% \times 100$ & 24 \\
\hline 4 & Sidomulyo Timur & 27.696 & 20 & $20 \% \times 100$ & 20 \\
\hline 5 & Wonorejo & 21.418 & 16 & $16 \% \times 100$ & 16 \\
\hline \multicolumn{2}{|c|}{ Jumlah } & $\mathbf{1 3 7 . 6 5 8}$ & $\mathbf{1 0 0}$ & & $\mathbf{1 0 0}$ \\
\hline
\end{tabular}

Sumber : Badan Pusat Statisti Kota Pekanbaru 2014, (diolah)

Berdasarkan tabel 2 di atas dapat diketahui bahwa jumlah responden yang diambil dari Kecamatan Marpoyan Damai adalah sebanyak 100 orang, yang masing-masing Kelurahan memiliki pengambilan sampel yang berbeda. Banyaknya sampel di Kelurahan Tangkerang Tengah adalah sebanyak 26 orang atau $26 \%$ dari perbandingan jumlah penduduk di kelurahan dengan jumlah penduduk Kecamatan Marpoyan Damai Kota Pekanbaru, jumlah responden dari Kelurahan Tangkerang Barat adalah sebanyak 14 orang atau $14 \%$, jumlah responden yang diambil dari kelurahan Maharatu adalah sebanyak 24 orang atau $24 \%$, dan jumlah responden yang diambil dari Kelurahan Sidomulyo Timur adalah sebanyak 20 orang atau $20 \%$, serta jumlah responden yang diambil dari kelurahan Wonorejo adalah sebanyak 16 orang atau $16 \%$ dari persentase jumlah penduduk kelurahan dengan penduduk kecamatan Marpoyan Damai Kota Pekanbaru.

Sampel dalam penelitian ini adalah wanita (ibu-ibu rumah tangga) yang bersuami dan bekerja serta berusia antara 17-50 tahun yang berdomisili di Kecamatan Marpoyan Damai Kota Pekanbaru. Adapun tekhnik pengambilan sampel adalah dengan menggunakan Sampling Insidental atau yang merupakan teknik penentuan sampel berdasarkan kebetulan, yaitu siapa saja yang secara kebetulan atau insidental bertemu dengan peneliti dapat digunakan sebagai sampel, bila dipandang orang yang kebetulan ditemui itu cocok sebagai sumber data. ${ }^{23}$ 
Yessi Nesneri dan Virna Museliza: Motivasi Wanita Bekerja \& Pengaruhnya terhadap Kontribusi Pendapatan Wanita dalam Membantu Pendapatan Keluarga di Kecamatan Marpoyan Damai Kota Pekanbaru

\section{Metode Analisa Data}

Dalam menganalisis data yang diperoleh dari objek penelitian ini penulis menggunakan Analisis Deskriptif Kuantitatif.Analisis deskriptif adalah analisis tentang karakteristik dari suatu keadaan dari objek yang diteliti.Analisis ini mengemukakan data-data responden khususnya tentang motivasi responden bekerja dan yang mendorong wanita untuk bekerja.Analisis kuantitatif adalah analisis yang digunakan untuk mengolah data yang diperoleh dari daftar pertanyaan wawancara kedalam bentuk angka-angka dan perhitungan dengan metode statistik. Dalam penelitian ini menggunakan program Statistical Product And Service Solution (SPSS) versi 22.

Untuk menganalisa data penulis menggunakan metode Regresi Linear Berganda, yaitu suatu metode statistik yang digunakan untuk mengetahui hubunganantara variabel bebas dan terikat yang dibantu dengan menggunakan program SPSS versi 22. Analisis regresi linear berganda memberikan kemudahan bagi pengguna untuk memasukan lebih dari satu variabel yang di tunjukan dengan persamaan :

$$
Y=a+b_{1} X_{1}+b_{2} X_{2}+b_{3} X_{3}+
$$

Keterangan :

$$
\begin{array}{lll}
\mathrm{Y}= & \text { Kontribusi Pendapatan } \\
& \text { Wanita UntukPendapatan } \\
& \text { Keluarga } \\
= & \text { Konstanta } \\
\mathrm{a}= & \text { Koefisien Regresi } \\
\mathrm{b}_{1}, \mathrm{~b}_{2}, \mathrm{~b}_{3}= & \text { Pendapatan Wanita } \\
\mathrm{X}_{1} & = & \text { Alokasi Waktu Bekerja } \\
\mathrm{X}_{2} & = & \text { Jumlah Tanggungan } \\
\mathrm{X}_{3} & \text { Keluarga } \\
\tilde{o} & = & \text { Tingkat Kesalahan (error) }
\end{array}
$$

\section{HASIL PENELITIAN DAN PEMBAHASAN}

Setelah melakukan penelitian dan pengamatan di daerah Kecamatan Marpoyan Damai, maka dapat dikemukakan hasil penelitian sebagai berikut:

\section{Analisis Deskriptif Motivasi Wanita Bekerja}

Motivasi wanita bekerja merupakan faktor penentu yang paling dasar dari keinginan dan perilaku seseorang karena dari motivasi atau dorongan tersebut akan memperkuat adanya keinginan berkontribusi terhadap pendapatan keluarga. Mengingat terjadinya peningkatan ekonomi rumah tangga.

Adapun tanggapan responden terhadap pertanyaan motivasi wanita bekerja dapat dilihat pada tabel 3 berikut ini: 
Tabel 3 : Tanggapan Responden Tentang Motivasi Wanita Bekerja

\begin{tabular}{|l|c|c|}
\hline \multicolumn{1}{|c|}{ Motivasi Wanita Bekerja } & Frekuensi & Persentase (\%) \\
\hline Pemantapan Identitas & 1 & 1 \\
\hline Mendapatkan relasi/ teman/ hubungan & 4 & 4 \\
\hline Mempraktekkan Ilmu dan Keterampilan & 7 & 7 \\
\hline Membantu Suami & 21 & 21 \\
\hline Meningkatkan Pendapatan Keluarga & 67 & 67 \\
\hline Total & $\mathbf{1 0 0}$ & $\mathbf{1 0 0}$ \\
\hline
\end{tabular}

Sumber : Data Olahan Penelitian 2014

Dari tabel 3 di atas dapat diketahui bahwa motivasi sebagian besar wanita bekerja adalah untuk meningkatkan pendapatan keluarga, yakni mencapai 67 orang (67\%), untuk membantu suami sebanyak 21 orang (21\%), untuk mempraktekkan ilmu dan keterampilan sebanyak 7orang (7\%), untuk mendapatkan relasi/ teman/ hubungan sebanyak 4 orang (4\%) dan untuk pemantapan identitas sebanyak 1 orang $(1 \%)$. Maka dapat disimpulkan bahwa wanita termotivasi bekerja adalah untuk meningkatkan pendapatan keluarga.Mengingat semakin tingginya kebutuhan rumah tangga.

Selanjutnya tanggapan responden tentang yang mendorong wanita bekerja dapat dilihat pada tabel 4 berikut ini :

Tabel 4 : Tanggapan Responden Tentang Yang Mendorong Wanita Bekerja

\begin{tabular}{|l|c|c|}
\hline Faktor Pendorong Wanita Bekerja & Frekuensi & Persentase (\%) \\
\hline Dorongan diri sendiri & 72 & 72 \\
\hline Dorongan Suami & 19 & 19 \\
\hline Dorongan Orang Tua & 1 & 1 \\
\hline Dorongan Lainnya & 8 & 8 \\
\hline \multicolumn{1}{|c|}{ Total } & $\mathbf{1 0 0}$ & $\mathbf{1 0 0}$ \\
\hline
\end{tabular}

Sumber : Data Olahan Penelitian 2014

Dari tabel 4 di atas dapat diketahui bahwa pihak yang mendorong wanita bekerja sebagian besar adalah dirinya sendiri yakni sebanyak 72 orang $(72 \%)$, dorongan suami yakni sebanyak 19 orang (19\%) dorongan dari orang tua sebanyak 1 orang (1\%) serta dorongan dari pihak lainnya sebanyak 8 orang $(8 \%)$. Dari hasil 
Yessi Nesneri dan Virna Museliza: Motivasi Wanita Bekerja \& Pengaruhnya terhadap Kontribusi Pendapatan Wanita dalam Membantu Pendapatan Keluarga di Kecamatan Marpoyan Damai Kota Pekanbaru

pengamatan tersebut maka dapat disimpulkan bahwa dorongan wanita untuk bekerja berasal dari dirinya sendiri hal ini sejalan dengan meningkatnya biaya hidup rumah tangga dan kesadaran wanita untuk ikut berperan dalam meringankan beban keluarga dengan memberikan pendapatannya untuk digunakan dalam memenuhi kebutahan hidup dengan kata lain wanita dapat berkontribusi terhadap pendapatan keluarga.

\section{Analisis Deskriptif Variabel Pendapatan Wanita $\left(X_{1}\right)$}

Pendapatan wanita adalah salah salah satu faktor yang mempunyai pengaruh langsung terhadap kontribusi pendapatan rumah tangga, dimana pendapatan wanita (ibu rumah tangga) merupakan semua penerimaan wanita yang didapatkan dari hasilnya bekerja.

Adapun tanggapan responden terhadap pertanyaan pendapatan wanita (ibu rumah tangga) dapat dilihat pada tabel 4.3 berikut ini:

Tabel 5: Tanggapan Responden Tentang Pendapatan Wanita (Ibu Rumah Tangga)

\begin{tabular}{|c|c|c|}
\hline Pendapatan Wanita & Frekuensi & Persentase (\%) \\
\hline$<1.000 .000$ & 6 & 6 \\
\hline $1.000 .000-2.000 .000$ & 47 & 47 \\
\hline $2.100 .000-3.000 .000$ & 40 & 40 \\
\hline $3.100 .000-4.000 .000$ & 7 & 0 \\
\hline$>4.000 .000$ & 0 & $\mathbf{1 0 0}$ \\
\hline Total & $\mathbf{1 0 0}$ & 7 \\
\hline
\end{tabular}

Sumber : Data Olahan Penelitian 2014

Dari tabel 5 di atas dapat diketahui bahwa rata-rata pendapatan wanita bekerja adalah berkisar antara 1.000.000-2.000.000 yakni sebanyak 47 orang responden $(47 \%)$, selanjutnya ibu yang berpendapatan $2.100 .000-$ 3.000 .000 adalah sebanyak 40 orang $(40 \%)$, wanita yang mendapatkan pendapatan 3.100.000-4.000.000 adalah sebanyak 7 orang $(7 \%)$, dan tidak ada wanita yang mendapatkan pendapatan lebih besar dari 4.000 .000 (0\%). Dengan demikian dapat disimpulkan bahwa rata-rata pendapatan wanita yang bekerja adalah berkisar antara 1.000.000 - 3.000.000, Artinya ibu yang bekerja memberikan kontribusi pendapatan yang cukup besar terhadap pendapatan rumah tangga. Bahkan ada beberapa responden yang menyatakan bahwa penghasilannya lebih besar di bandingkan dengan suaminya yang sejatinya berperan sebagai kepala rumah tangga. 
Analisis Deskriptif Variabel Alokasi Waktu Bekerja $\left(\mathrm{X}_{2}\right)$

Alokasi waktu bekerja merupakan banyaknya waktu yang dicurahkan untuk bekerja, yang diukur dalam satuan jam perhari.Hal ini perlu dilakukan, mengingat peranan wanita yang sangat banyak, diantaranya; peranan wanita sebagai isteri, dan ibu dari anak-anaknya; sebagai salah satu kelompok dari peranan sosialnya serta sebagai anggota masyarakat dari lingkungannya. Di samping itu wanita juga dapat berperan sebagai pencari nafkah tambahan bagi keluarganya.

Alokasi waktu bekerja menunjukkan banyaknya jam kerja yang dialokasikan oleh tenaga kerja wanita di Kecamatan Marpoyan Damai. Peningkatan jam kerja tenaga kerja wanita bertujuan untuk lebih meningkatkan pendapatan atau mendapatkan penghasilan yang lebih besar, karena semakin lama waktu dialokasikan untuk bekerja maka semakin tinggi pendapatan yang akan diterima. Akan tetapi wanita harus tetap mengetahui danmelakukan kewajibannya sebagai ibu rumah tangga, yang tentunya akan menuntut peran ganda yang optimal.

Adapun tanggapan responden terhadap alokasi waktu bekerja dapat dilihat pada tabel 6 berikut ini:

Tabel 6: Tanggapan Responden tentang Alokasi Waktu Bekerja

\begin{tabular}{|c|c|c|}
\hline Alokasi Waktu Bekerja & Frekuensi & Persentase (\%) \\
\hline 4 Jam & 2 & 2 \\
\hline 5 Jam & 4 & 4 \\
\hline 6 Jam & 6 & 6 \\
\hline 7 Jam & 30 & 30 \\
\hline 8 Jam & 58 & 58 \\
\hline Total & $\mathbf{1 0 0}$ & $\mathbf{1 0 0}$ \\
\hline
\end{tabular}

Sumber : Data Olahan Penelitian 2014

Dari tabel 6 di atas dapat diketahui bahwa sebagian besar responden mengalokasikan waktu bekerja sebanyak 8 jam dalam sehari, hal ini terbukti dari tanggapan responden terhadap pertanyaan pada wawancara yakni 58 responden (58\%) yang menyatakan 8 jam dalam sehari untuk bekerja, karena kebanyakan responden bekerja sebagai pedagang dan asisten rumah tangga. Selanjutnya sebanyak 30 responden $(30 \%)$ menyatakan alokasi waktu bekerja dalam sehari adalah sebanyak 7 jam, di susul oleh 6 responden $(6 \%)$ menyatakan bahwa alokasi waktu untuk bekerja adalah 6 
Yessi Nesneri dan Virna Museliza: Motivasi Wanita Bekerja \& Pengaruhnya terhadap Kontribusi Pendapatan Wanita dalam Membantu Pendapatan Keluarga di Kecamatan Marpoyan Damai Kota Pekanbaru

jam. Sedangkan responden yang menyatakan alokasi waktu untuk bekerja 5 jam dalam sehari adalah sebanyak 4 responden $(4 \%)$, dan 2 orang responden $(2 \%)$ menyatakan alokasi waktunya untuk bekerja dalam sehari adalah 4 jam. Dari hasil pengamatan tersebut maka dapat disimpulkan bahwa sebagian besar alokasi waktu responden untuk bekerja adalah 8 jam dalam sehari, akan tetapi walaupun waktu bekerjanya adalah 8 jam dalam sehari, wanita (ibu rumah tangga) tetap bisa mengontrol dan mengawasi rumah tangganya, karena didukung oleh lokasi kerja yang tidak jauh dari rumah, sebab sebagian besar responden adalah pedagang didekat rumahnya sendiri, dan juga sebagai asisten rumah tangga untuk wilayah sekitar tempat tinggalnya saja.

\section{Analisis Deskriptif Variabel Jumlah Tanggungan Keluarga $\left(X_{3}\right)$}

Motivasi wanita dalam bekerja salah satunya dipengaruhi oleh tingginya kebutuhan peningkatan ekonomi rumah tangga yang dipicu oleh tingginya jumlah tanggungan keluarga.Jumlahtanggungan keluarga merupakan banyaknya anggota rumah tangga yang tidak produktif maupun yang produktif, yang secara ekonomis menjadi tanggungan dalam keluarga, dengan satuan yang digunakan adalah orang (jiwa).

Adapun tanggapan responden tentang jumlah tanggungan keluarga dapat dilihat pada tabel 7 berikut ini:

Tabel 7: Tanggapan Responden tentang Jumlah Tanggungan Keluarga

\begin{tabular}{|c|c|c|}
\hline Jumlah Tanggungan Keluarga & Frekuensi & Persentase (\%) \\
\hline 1 orang & 4 & 4 \\
\hline 2 orang & 11 & 11 \\
\hline 3 orang & 15 & 15 \\
\hline 4 orang & 42 & 42 \\
\hline$>4$ orang & 28 & 28 \\
\hline Total & $\mathbf{1 0 0}$ & $\mathbf{1 0 0}$ \\
\hline
\end{tabular}

Sumber : Data Olahan Penelitian 2014

Dari tabel 7 di atas dapat diketahui bahwa sebagian besar responden memiliki anggota keluarga cukup banyak, yakni 4 orang sebanyak 42 responden $(42 \%)$, jumlah anggota keluarga yang lebih dari 4 orang $(>4$ orang) sebanyak 28 responden (28\%), jumlah anggota keluarga 3 orang sebanyak 15 responden (15\%), danjumlah keluarga 2 orang sebanyak 11 responden (11\%), sertajumlahanggota keluarga yang berjumlah 1 orang hanya 4 responden 
(4\%). Maka dapat disimpulkan bahwa jumlah tanggungan responden cukup besar yakni berkisar 4 orang anggota keluarga bahkan lebih dari empat anggota keluarga, hal ini mengindikasikan bahwa jumlah anggota keluarga akan mempengaruhi tingkat konsumsi dan beban hidup yang ditanggung. Jika jumlah tanggungan keluarga cukup besar maka beban hidup juga semakin besar. Hal ini akan mempengaruhi tingkat kesejahteraan perekonomian rumah tangga.

Kontribusi Pendapatan Wanita Untuk Pendapatan Keluarga (Y)

Pendapatan wanita (ibu rumah tangga) merupakan pendapatan yang diterima sebagai imbalan atau balas jasa atas kinerja yang dilakukan seorang wanita (ibu rumah tangga). Dengan kata lain, kontribusi pendapatan wanita (ibu rumah tangga) merupakan pendapatan ibu yang diberikan oleh ibu rumah tangga untuk dapat memenuhi kebutuhan rumah tangganya dan meningkatkan kehidupan ekonomi rumah tangga agar kebutuhan untuk seluruh anggota keluarga terpenuhi dengan layak.

Pendapatan keluarga merupakan pendapatan yang dihasilkan suami dan anggota keluarga lainnya termasuk pendapatan ibu yang digunakan untuk memenuhi seluruh kebutuhan hidup dalam keluarga tersebut. Dalam penelitian ini kontribusi wanita (ibu rumah tangga) diukur dengan cara : Pendapatan wanita (ibu rumah tangga) dibagi dengan total pendapatan keluarga (pendapatan wanita + pendapatan suami + pendapatan lain-lain) di kali dengan $100 \%$.

Adapun hasil wawancara dengan responden adalah diketahui pendapatan wanita, pendapatan suami, dan pendapatan lain-lain yang dapat dilihat pada tabel 8 berikut ini:

Tabel 8: Pendapatan Keluarga

\begin{tabular}{|c|c|c|c|c|c|c|}
\hline Pendapatan & $\begin{array}{c}\text { Frekuensi } \\
\text { Pendapatan } \\
\text { Wanita }\end{array}$ & $\mathbf{( \% )}$ & $\begin{array}{c}\text { Frekuensi } \\
\text { Pendapatan } \\
\text { Suami }\end{array}$ & $\mathbf{( \% )}$ & $\begin{array}{c}\text { Frekuensi } \\
\text { Pendapatan } \\
\text { Lain-lain }\end{array}$ & $\mathbf{( \% )}$ \\
\hline$<1.000 .000$ & 6 & 6 & 6 & 6 & 10 & 10 \\
\hline $1.000 .000-2.000 .000$ & 47 & 47 & 65 & 65 & 1 & 1 \\
\hline $2.100 .000-3.000 .000$ & 40 & 40 & 26 & 26 & 0 & 0 \\
\hline $3.100 .000-4.000 .000$ & 7 & 7 & 3 & 3 & 0 & 0 \\
\hline$>4.000 .000$ & 0 & 0 & 0 & 0 & 0 & 0 \\
\hline Total & $\mathbf{1 0 0}$ & $\mathbf{1 0 0}$ & $\mathbf{1 0 0}$ & $\mathbf{1 0 0}$ & $\mathbf{1 1}$ & $\mathbf{1 1}$ \\
\hline
\end{tabular}

Sumber : Data Olahan Penelitian 2014 
Yessi Nesneri dan Virna Museliza: Motivasi Wanita Bekerja \& Pengaruhnya terhadap Kontribusi Pendapatan Wanita dalam Membantu Pendapatan Keluarga di Kecamatan Marpoyan Damai Kota Pekanbaru

Dari tabel 8 di atas dapat diketahui sebagian besar dari responden memberikaninformasibahwa pendapatan suami lebih kecil dibandingkan dengan pendapatan wanita (ibu rumah tangga), hal ini bisa terlihat bahwa pendapatan suami responden hanya berkisar antara 1.000 .000 - 2.000 .000 yakni sebanyak 65 responden $(65 \%)$. Dan yang mempunyai pendapatan 2.100.000 - 3.000.000,.yakni sebanyak 26 responden (26\%). Bila di bandingkan dengan pendapatan wanita, maka pendapatan wanita terlihat lebih tinggi dibandingkan dengan pendapatan suami yaitu untuk kategori pendapatan 2.100.000 - 3.000.000 adalah sebanyak 40 responden $(40 \%)$, sedangkan pendapatan wanita dalam kategori $1.000 .000-2.000 .000$ adalah sebanyak 47 responden (47\%), selain itu, dari tabel 5 . 11 diatas dapat diketahui bahwa hanya sebanyak 11 responden (11\%) yang mempunyai pendapatan tambahan (pendapatan lain-lain) dari anggota keluarga lainnya, yakni yang diberikan oleh seorang anak yang sudah bekerja. Sedangkan sekitar 89 responden (89\%) masih berjuang untuk memenuhi kebutuhan rumah tangga baik untuk konsumsi, transportasi, pendidikan dan komunikasi agar hidup layak dan peningkatan strata sosial dapat diwujudkan.

Selanjutnya dari informasi yang diberikan oleh responden maka dapat diketahui kontribusi pendapatan wanita untuk pendapatan keluarga yang dapat dilihat pada tabel 9 berikut ini:

Tabel 9 :Kontribusi Pendapatan Ibu Rumah Tangga (Wanita) Untuk Pendapatan Keluarga

\begin{tabular}{|c|c|c|}
\hline $\begin{array}{c}\text { Kontribusi Pendapatan Wanita } \\
\text { (Dalam Persentase) }\end{array}$ & Frekuensi & $\begin{array}{c}\text { Persentase } \\
\mathbf{( \% )}\end{array}$ \\
\hline $10-30 \%$ & 2 & 2 \\
\hline $31-50 \%$ & 42 & 42 \\
\hline $51-70 \%$ & 50 & 50 \\
\hline $71-90 \%$ & 6 & 6 \\
\hline$>90 \%$ & 0 & 0 \\
\hline Total & $\mathbf{1 0 0}$ & $\mathbf{1 0 0}$ \\
\hline
\end{tabular}

Dari tabel 9 di atas dapat diketahui bahwa kontribusi pendapatan wanita (ibu rumah tangga) terhadap pendapatan keluarga cukup besar.Yakni terlihat dari hasil pengamatan ada 50 responden (50\%) yang memberikan kontribusinya untuk pendapatan keluarga sebesar 51 - 70\%. Hal ini membuktikan bahwa kontribusi pendapatan wanita melebihi dari pendapatan kepala keluarga yang semestinya berperan memenuhi 
kebutuhan hidup sehari- hari untuk meningkatkan ekonomi keluarga, dari hasil pengamatan juga didapatkan bahwa terdapat 42 responden (42\%) yang memberikan kontribusi pendapatannya untuk pendapatan keluarga sebesar 31 $50 \%$, dan terdapat 6 wanita (ibu rumah tangga) yang memberikan kontribusi untuk pendapatan keluarga sebesar 71 $90 \%$, serta responden yang memberikan kontribusinya dengan angka $10-30 \%$ hanya sebanyak 2 orang responden. Maka dapat disimpulkan bahwa sebagian besar responden merupakan tulang punggung utama dalam keluarga, di antara penyebab wanita harus berperan bahkan dituntut untuk mempunyai penghasilan karena kepala rumah tangga hanya memiliki sedikit penghasilan sebab kurangnya keterampilan yang dimiliki dan kurangnya kesadaran dalam memenuhi nafkah kepada isteri dan seluruh anggota keluarga.

Dalam Islam, seharusnya suamilah yang memenuhi kebutuhan hidup keluarga serta meningkatkan ekonomi rumah tangga. Menurut Abu Ibrahim Muhammad Ali AM, hafidzahullah dalam tulisannya Fiqih Nafkah menjelaskan bahwasanya seorang laki-laki jika menikahi wanita, maka wajib baginya memberi nafkah, hal ini didasari oleh beberapa hal sebagai berikut:

a. Firman Allah dalam Al-Qur'anSurat Al- Baqarah ayat 228 yang artiya "dan Para wanita mempunyai hak yang seimbang dengan kewajibannya menurut cara yang ma'ruf". (QS.AlBaqarah ayat 228)

Hal ini disebabkan karena suami bertanggung jawab terhadap keselamatan dan Kesejahteraan rumah tangga.Bukan sebaliknya, seperti yang terjadi zaman sekarang. Akan tetapi, apabila isteri bekerja dengan ridho untuk mencari nafkah dan kesejahteraan keluarga, maka itu akan menjadi pahala bagi sang isteri / wanita.

b. Tafsir Al- Qur'anil Adhim 1/272 yang menyatakan:

Ibnu Katsir berkata, "maksudnya para isteri mempunyai hak diberi nafkah oleh suaminya yang seimbang dengan hak suamiyang diberikanoleh isterinya, maka hendaklah masingmasing menunaikan kewajibannya dengan cara yang makruf dan hal itu mencakupkewajiban suami memberi nafkah isterinya, sebagaimana hakhak lainnya.

c. Sabda RasulullahSAW Yang artinya sebagai berikut:

"Dan mereka (para isteri) mempunyai hak diberi rizki dan pakaian (nafkah) yang diwajibkan atas kamu sekalian (wahaipara suami)".

\section{Analisis Regresi Linier Berganda}

Dalam penelitian ini penulis menggunakan analisis Regresi Linier Berganda untuk mengetahui 
Yessi Nesneri dan Virna Museliza: Motivasi Wanita Bekerja \& Pengaruhnya terhadap Kontribusi Pendapatan Wanita dalam Membantu Pendapatan Keluarga di Kecamatan Marpoyan Damai Kota Pekanbaru

pengaruh variabel bebas yang terdiri dari (Pendapatan Wanita, Alokasi Waktu Bekerja dan Jumlah Tanggungan Keluarga) terhadap variabel terikat (Kontribusi Wanita
Untuk Pendapatan Keluarga) dengan menggunakan regresi linear berganda. Hasil Analisis Regresi Linier Berganda dapat dilihat pada tabel 4.8 berikut ini:

Tabel 10 Hasil Analisis Regresi Linear Berganda

Coefficients $^{\mathrm{a}}$

\begin{tabular}{|c|c|c|c|c|c|}
\hline \multirow[b]{2}{*}{ Model } & \multicolumn{2}{|c|}{$\begin{array}{l}\text { Unstandardized } \\
\text { Coefficients }\end{array}$} & \multirow{2}{*}{$\begin{array}{c}\begin{array}{c}\text { Standardized } \\
\text { Coefficients }\end{array} \\
\text { Beta }\end{array}$} & \multirow[b]{2}{*}{$\mathrm{t}$} & \multirow[b]{2}{*}{ Sig. } \\
\hline & B & Std. Error & & & \\
\hline 1 (Constant) & 28.886 & 8.827 & & 3.494 & .001 \\
\hline Pendapatan Wanita & 1.119 & .000 & .655 & 6.170 & .000 \\
\hline Alokasi Waktu Bekerja & -.631 & 1.344 & -.050 & -.469 & .640 \\
\hline $\begin{array}{l}\text { Jumlah Tanggungan } \\
\text { Keluarga }\end{array}$ & 1.214 & .711 & .235 & 2.009 & .041 \\
\hline
\end{tabular}

Sumber : Data Olahan Penelitian 2014

a. Dependent Variabel: Kontribusi

Pendapatan Wanita Untuk

Pendapatan Keluarga

Berdasarkan tabel 4.8 diatas dapat diketahui persamaan regresi sebagai berikut:

Perilaku Konsumen (Y) $=\mathrm{a}+\mathrm{b}_{1} \mathrm{X}_{1}+$ $\mathrm{b}_{2} \mathrm{X}_{2}+\mathrm{b}_{3} \mathrm{X}_{3}+$ $\mathrm{b}_{3} \mathrm{X}_{3}+\tilde{\mathrm{o}}$

Perilaku Konsumen $(\mathrm{Y})=28.886+$ $1,119 X_{1}-$ $0,631 \mathrm{X}_{2}$ $+1,214 X_{3}+\tilde{o}$

Arti angka-angka dalam persamaan regresi diatas:

1. Variabel Y (Perilaku Konsumen) mempunyai nilai konstanta sebesar 28.886. Ini berarti bahwa jika variabel independen dianggap konstan, maka kontribusi pendapatan wanita untuk pendapatan keluarga adalah sebesar 28.886 satuan.

2. Nilai koefisien regresi variabel Pendapatan Wanita $\left(X_{1}\right)$ adalah sebesar 1,119, Artinya adalah Setiap kenaikan atau peningkatan 1 (satu) satuan Pendapatan wanita akan meningkatkan kontribusi pendapatan wanita untuk pendapatan keluarga sebesar 1,119 satuan.

3. Nilai koefisien regresi variabel 
Alokasi Waktu Bekerja $\left(\mathrm{X}_{2}\right)$ adalah sebesar-0,631, Artinya adalah Setiap kenaikan atau peningkatan 1 (satu) satuan Alokasi Waktu Bekerja maka akan menurunkan kontribusi pendapatan wanita untuk pendapatan keluarga sebesar 0, 631 satuan.

4. Nilai koefisien regresi variabel Jumlah Tanggungan Keluarga $\left(\mathrm{X}_{3}\right)$ adalah sebesar 1,214, Artinya adalah Setiap kenaikan atau peningkatan 1 (satu) satuan Jumlah Tanggungan Keluarga maka akan meningkatkan kontribusi pendapatan wanita untuk pendapatan keluarga sebesar 1, 214 satuan.

5. Standar error (e) merupakan variabel acak dan mempunyai disteribusi probabilitas. Standar error $(e)$ mewakili semua faktor yang mempunyai pengaruh terhadap Variabel $\mathrm{Y}$ tetapi tidak dimasukan dalam persamaan.

\section{Uji Hipotesis}

\section{Uji F (Uji Simultan)}

Uji F (Uji Simultan) ini digunakan untukmelihatpengaruhdarivariabel bebas yang terdiri dari (Pendapatan Wanita, Alokasi Waktu Bekerja dan Jumlah Tanggungan Keluarga) terhadap variabel terikat (Kontribusi Pendapatan Wanita untuk Pendapatan Keluarga) secara bersama-sama atau serentak. Yaitu caranya dengan membandingkan antara $\mathrm{F}$ hitung dengan $\mathrm{F}$ tabel. Dengan tingkat signifikan 0,05 jika F hitung $>\mathrm{F}$ tabel berarti variabel bebas bersama-sama berpengaruh sangat nyata terhadap variabel terikat maka, namunjikaFhitung < F tabel berartivariabel bebas tidak berpengaruh terhadap variabel terikat.

Berdasarkan uji f (uji simultan) yang dilakukan, diperoleh nilai kofisien korelasi dan regresi sebagai berikut :

Tabel 11 Hasil Uji F (Uji Simultan)

ANOVA $^{b}$

\begin{tabular}{|c|c|c|c|c|c|}
\hline Model & Sum of Squares & Df & Mean Square & $\mathrm{F}$ & Sig. \\
\hline Regression & 5391.846 & 3 & 1797.282 & 21.653 & $.000^{\mathrm{b}}$ \\
\hline Residual & 7968.478 & 96 & 83.005 & & \\
\hline Total & 13360.323 & 99 & & & \\
\hline
\end{tabular}

Sumber : Data Olahan Penelitian 2014

a. Dependent Variable: Kontribusi Pendapatan Wanita Untuk Pendapatan Keluarga

b. Predictors: (Constant), Jumlah Tanggungan Keluarga, Pendapatan Wanita, Alokasi Waktu Bekerja
Dari tabel 11 diatas Diketahui F hitung sebesar 21.653 dengan signifikansi 0,000. Dan F tabel dapat diperoleh sebagai berikut:

$$
\begin{aligned}
& \mathrm{F} \text { tabel }=\mathrm{df} 1=\mathrm{k}-1=4-1=3 \\
& \mathrm{~F} \text { tabel }=\mathrm{df} 2=\mathrm{n}-\mathrm{k}=100-4=96
\end{aligned}
$$


Yessi Nesneri dan Virna Museliza: Motivasi Wanita Bekerja \& Pengaruhnya terhadap Kontribusi Pendapatan Wanita dalam Membantu Pendapatan Keluarga di Kecamatan Marpoyan Damai Kota Pekanbaru

$$
\begin{aligned}
& \mathrm{F} \text { tabel }=96 ; 3 \\
& \mathrm{~F} \text { tabel }=2,70(\mathrm{~F} \text { tabel } 0.05)
\end{aligned}
$$

Keterangan $n$ : jumlah sampel $\mathrm{k}$ : jumlah variabel bebas dan terikat

$$
\text { 1: konstan }
$$

Dengan demikian diketahui $\mathrm{F}$ hitung (21.653) > F tabel $(2,70)$ dengan Sig. $(0,000)<0,05$. Artinya adalah bahwa variabel bebas (Pendapatan Wanita, Alokasi Waktu Bekerja, dan Jumlah Tanggungan Keluarga) secara bersamasama atau serentak berpengaruh signifikan terhadap variabel terikat (Kontribusi Pendapatan Wanita Untuk Pendapatan Keluarga).

\section{Uji t (Uji Parsial)}

Uji t (Uji Parsial) digunakan untuk menguji hubungan koefisien regresi secara parsial atau terpisah dari variabel independennya, apakah masing-masing variabel bebas berpengaruh terhadap variabel
terikat.Caranya adalah dengan membandingkan antara thitung dengan $\mathrm{t}$ tabel. Jika thitung $>\mathrm{t}$ tabel maka berarti masing-masing variabel bebas atau variabel independen (Pendapatan Wanita, Alokasi Waktu Bekerja, dan Jumlah Tanggungan Keluarga) mempunyai pengaruh terhadap variabel terikat atau variabel dependen (Kontribusi Pendapatan Wanita Untuk Pendapatan Keluarga), namun jika $t$ hitung $<\mathrm{t}$ tabel maka berarti masingmasing variabel bebas atau variabel independen (Pendapatan Wanita, Alokasi Waktu Bekerja, dan Jumlah Tanggungan Keluarga) tidak berpengaruh terhadap variabel terikat atau variabel dependen (Kontribusi Pendapatan Wanita Untuk Pendapatan Keluarga).

Berdasarkan uji t (uji parsial) yang dilakukan, diperoleh nilai variabel Pendapatan Wanita, Alokasi Waktu Bekerja, dan Jumlah Tanggungan Keluarga pada tabel 4.10 berikut ini: 
Tabel 12: Hasil Uji t (Uji Parsial)

Coefficients $^{\mathrm{a}}$

\begin{tabular}{|c|c|c|c|c|c|}
\hline \multirow[b]{2}{*}{ Model } & \multicolumn{2}{|c|}{ Unstandardized Coefficients } & \multirow{2}{*}{$\begin{array}{c}\begin{array}{c}\text { Standardized } \\
\text { Coefficients }\end{array} \\
\text { Beta }\end{array}$} & \multirow[b]{2}{*}{$\mathrm{t}$} & \multirow[b]{2}{*}{ Sig. } \\
\hline & B & Std. Error & & & \\
\hline 1 (Constant) & 28.886 & 8.827 & & 3.494 & .001 \\
\hline $\begin{array}{l}\text { Pendapatan } \\
\text { Wanita }\end{array}$ & 1.119 & .000 & .655 & 6.170 & .000 \\
\hline $\begin{array}{l}\text { Alokasi } \\
\text { Waktu } \\
\text { Bekerja }\end{array}$ & -.631 & 1.344 & -.050 & -.469 & .640 \\
\hline $\begin{array}{l}\text { Jumlah } \\
\text { Tanggungan } \\
\text { Keluarga }\end{array}$ & 1.214 & .711 & .135 & 2.009 & .041 \\
\hline
\end{tabular}

Sumber : Data Olahan Penelitian 2014

Dari tabel 12 diatas dapat diketahui nilai $\mathrm{t}$ tabel pada taraf signifikansi $5 \%$ (2-tailed) dengan Persamaan berikut:

$$
\begin{aligned}
\mathrm{t} \text { tabel } & =\mathrm{n}-\mathrm{k}-1: \text { alpha } / 2 \\
& =100-4-1: 0,05 / 2 \\
& =95: 0,025=1,985
\end{aligned}
$$

keterangan:

$\mathrm{n}$ : jumlah sampel

$\mathrm{k}$ : jumlah variabel bebas dan terikat

$1:$ konstan

1. Variabel Pendapatan Wanita. Diketahui $\mathrm{t}_{\text {hitung }}(6,170)>\mathrm{t}_{\text {tabel }}(1,985)$ danSig. $(0,001)<0,05$. Artinya variabel Pendapatan Wanita berpengaruh signifikan terhadap Kontribusi Pendapatan Wanita Untuk Pendapatan Keluarga.

2. Variabel Alokasi Waktu Bekerja. Diketahui $\mathrm{t}_{\text {hitung }}(-0,469)<\mathrm{t}_{\text {tabel }}(1,985)$
danSig. $(0,640)>0,05$. Artinya variabel Alokasi Waktu Bekerja tidak berpengaruh signifikan terhadap Kontribusi Pendapatan Wanita Untuk Pendapatan Keluarga.

3. Variabel Jumlah Tanggungan Keluarga. Diketahui $\mathrm{t}_{\text {hitung }}(2,009)>\mathrm{t}$ tabel $(1,985)$ dan Sig. $(0,041)<0,05$. Artinya variabel Jumlah Tanggungan Keluarga berpengaruh signifikan terhadap Kontribusi Pendapatan Wanita Untuk Pendapatan Keluarga.

Uji Koefisien Determinasi $\left(\mathbf{R}^{2}\right)$

Uji Koefisien Determinasi $\left(\mathrm{R}^{2}\right)$ adalah untuk melihat sumbangan pengaruh variabel independen (Pendapatan Wanita, Alokasi Waktu Bekerja, dan Jumlah Tanggungan Keluarga) terhadap variabel dependen (Kontribusi Pendapatan Wanita Untuk Pendapatan Keluarga) 
Yessi Nesneri dan Virna Museliza: Motivasi Wanita Bekerja \& Pengaruhnya terhadap Kontribusi Pendapatan Wanita dalam Membantu Pendapatan Keluarga di Kecamatan Marpoyan Damai Kota Pekanbaru

Hasil uji koefisien determinasi

$\left(\mathrm{R}^{2}\right)$ dapat dilihat pada tabel 4.11 berikut ini:

Tabel 13 : Koefisien Determinasi

Model Summary ${ }^{b}$

\begin{tabular}{|l|r|r|r|r|r|}
\hline Model & $\mathrm{R}$ & R Square & \multicolumn{1}{c|}{$\begin{array}{c}\text { Adjusted R } \\
\text { Square }\end{array}$} & $\begin{array}{c}\text { Std. Error of the } \\
\text { Estimate }\end{array}$ & Durbin-Watson \\
\hline 1 & $.635 \mathrm{a}$ & .618 & .603 & 9.110 & 1.818 \\
\hline
\end{tabular}

Sumber : Data Olahan Penelitian 2014

a. Predictors: (Constant),Jumlah Tanggungan Keluarga, Pendapatan Wanita, Alokasi Waktu Bekerja

b. Dependent Variabel: Kontribusi Pendapatan Wanita Untuk Pendapatan Keluarga

Berdasarkan tabel 13 diatas diketahui nilai Adjusted $\mathrm{R}^{2}$ Square adalah sebesar 0,603 . Artinya adalah bahwa sumbangan pengaruh variabel independen terhadap variabel dependen adalah sebesar $60,3 \%$, sedangkan sisanya sebesar $39,7 \%$ dipengaruhi oleh variabel lain yang tidak dimasukkan dalam penelitian ini.

\section{KESIMPULAN}

Berdasarkan hasil penelitian dan analisis yang telah dilakukan mengenai motivasi wanita bekerja dan pengaruhnya terhadap kontribusi pendapatan wanita untuk pendapatan keluarga di Kecamatan Marpoyan Damai, maka penulis menarik kesimpulan sebagai berikut: 1. Motivasi wanita bekerja yang paling besar adalah untuk meningkatkan pendapatan keluarga, yakni mencapai $67 \%$ responden, hal ini di sebabkan oleh tingginya kebutuhan hidup, akibat kondisi perekonomian yang tidak stabil serta tuntutan hidup yang semakin kompleks.

2. Faktor yang mendorong wanita bekerja adalah karena dirinya sendiri, yakni sebesar $72 \%$. hal ini sejalan dengan meningkatnya biaya hidup rumah tangga dan kesadaran wanita untuk ikut berperan dalam meringankan beban keluarga dengan memberikan pendapatannya untuk digunakan dalam memenuhi kebutahan hidup dengan kata lain wanita dapat berkontribusi terhadap pendapatan keluarga.

3. Secara parsial, pendapatan wanita $\left(X_{1}\right)$ dan jumlah tanggungan keluarga $\left(\mathrm{X}_{3}\right)$ mempunyai pengaruh yang signifikan terhadap kontribusi pendapatan wanita untuk pendapatan keluarga di mana variabel pendapatan wanita $\left(X_{1}\right)$ 
memiliki nilai $\mathrm{t}_{\text {hitung }}$ sebesar $6,170>\mathrm{t}$ tabel $(1,985)$ dan Sig. $(0,001)<0,05$. dan variabel jumlah tanggungan keluarga $\left(X_{3}\right)$ memiliki nilai $t_{\text {hitung }}$ sebesar 2,009 $>\mathrm{t}_{\text {tabel }}(1,985)$ dan Sig. $(0,041)<0,05$, serta dari kedua variabel diatas dapat diketahui bahwa yang paling dominan berpengaruh terhadap kontribusi pendapatan wanita untuk keluarga adalah pendapatan wanita . Sedangkan alokasi waktu bekerja $\left(X_{2}\right)$ tidak mempunyai pengaruh yang signifikan terhadap kontribusi pendapatan wanita untuk pendapatan keluarga yakni nilai $\mathrm{t}_{\text {hitung }}$ sebesar $-0,469<\mathrm{t}_{\text {tabel }}$ $(1,985)$ dan Sig. $(0,640)>0,05$.

4. Berdasarkan UjiSecaraSimultan(Uji F) diketahui bahwa Semua variabel bebas (pendapatan wanita $\left(X_{1}\right)$, alokasi waktu bekerja $\left(X_{2}\right)$, dan jumlah tanggungan keluarga $\left(X_{3}\right)$ berpengaruh signifikan terhadap kontribusi pendapatan wanita untuk pendapatan keluarga dan nilainya positif dengan nilai $\mathrm{F}_{\text {hitung }}$ sebesar $21.653>\mathrm{F}_{\text {tabel }}(2,70)$.

5. Berdasarkan Uji Koefisien Determinasi $\left(\mathrm{R}^{2}\right)$ atau nilai Adjusted $\mathrm{R}^{2}$ Square adalah sebesar 0,603. Artinya adalah bahwa sumbangan pengaruh variabel bebas (independen) terhadap variabel terikat (dependen) adalah sebesar $60,3 \%$, sedangkan sisanya sebesar 39,7\% dipengaruhi oleh variabel lain yang tidak diteliti dalam penelitian ini.

\section{Endnotes:}

detik finance, 06/3/2014

2 Ummu Muhammad, 2009, http :// d1.islamhouse. comdata/id/ih_articles

Asyiek,dkkdalam Artini dan Handayani, 2009:10

4 Simanjuntak, 2001, Pengantar Ekonomi Sumber Daya Manusia. Edisi kedua. Jakarta: Lembaga Penerbit Fakultas Ekonomi Universitas Indonesia Ibid

6 Dumairy, 2004

7 Todaro, 2006

8 Ernie, 2005

9 Siagian, 2002

10 Hasibuan, 2008

11 Robbins, 2008

12 Siagian, 2002

13 Asyiek,dkk dalam Artini dan Handayani, 2009

14 Simanjuntak, 2001

15 Wahyu, 2004

16 Yuliana, 2007

17 Riana Mustika Agustin, 2010

18 T. Gilarso, 2004

19 Samuelson dan Nordhaus, 2002

20 Sugiyono, 2006

21 Umar, 2007

22 Arikunto, 2002

23 Sugiyono, 2013

\section{DAFTAR PUSTAKA}

Adji Wahyu. 2004. Ekonomi SMK. Bandung: Ganeca Exacta

Arikunto, S. 2002. Prosedur Suatu Penelitan: Pendekatan Praktek. Edisi Revisi Kelima. Jakarta : Penerbit Rineka Cipta.

Artini, Ni Wayan Putu dan Handayani. 2009. Kontribusi pendapatan Ibu Rumah Tangga Pembuat Makanan Olahan Terhadap Pendapatan Keluarga. Piramida, 5.1:9-15.

Badan Pusat Statistik Jakarta, 2009, data Kependudukan, Badan Pusat Statistik. Jakarta 
Yessi Nesneri dan Virna Museliza: Motivasi Wanita Bekerja \& Pengaruhnya terhadap Kontribusi Pendapatan Wanita dalam Membantu Pendapatan Keluarga di Kecamatan Marpoyan Damai Kota Pekanbaru

Detik Finance., 2014.m.detik.com/ finance/read/2014/03/06/ 134053/2517461/4. Diakses pada hari Selasa 1 April 2014.

Ernie, Tisnawati Sule dan Sefullah, Kurniawan. 2005. Pengantar Manajemen. Jakarta : Kencana.

Elizabeth, 2007. Pemberdayaan Wanita Mendukung Strategi Gender Dalam Kebijakan Pembangunan Pertanian di Pedesaan. Pusat Analisis Sosial Ekonomi dan Kebijakan pertanian. Bogor

Ghozali, Imam, 2005. Analisis Multivariate Dengan SPSS. Penerbit BP UNDIP; Semarang.

Gilarso, T.2004.PengantarIlmuEkonomi Makro, Yogyakarta: Kanisius.

Hasibuan, Malayu S. P. 2008. Manajemen Sumber Daya Manusia. Jakarta.

Riana, Mustika, Agustin, 2010. Peran Industri Kerajinan Kipas Bambu Dalam Penyerapan Tenaga Kerja, Pendapatan Keluarga dan Pendidikan Anak: Studi Kasus Di Desa Keprabon, Kecamatan Polanharjo Kabupaten Klaten, Jawa Tengah. Skripsi. Pendidikan Ekonomi. FISE.UNY
Samuelson, Paul, A dan Nordhaus D, William, 2002. Ekonomi, Edisi 12 Jilid 2. Jakarta: Erlangga.

Simanjuntak, P.J.(2001). Pengantar Ekonomi Sumber Daya Manusia. Edisi kedua. Jakarta: Lembaga Penerbit Fakultas Ekonomi Universitas Indonesia.

Simbolon. 2010. Faktor-faktor yang Mempengaruhi Partisi Angkatan Kerja Wanita di Kota Medan. Tesis .Meda.USU.

Sugiyono. 2006, Metode Penilitian Bisnis, Edisi ke Enam, Bandung : Penerbit CV Alfabeta.

- - - - - . 2006. Metode Penelitian Kuantitatif, Kualitatif dan R\&D, Cetakan ke Delapan Belas, Bandung: Penerbit CV Alfabeta.

Umar, Husein. 2007. Metode Penelitian Untuk Skripsi dan Tesis Bisnis. Jakarta:PT. Raja Grafindo Persada.

Ummu Muhammad, 2009 http :// d1.islamhouse.comdata/id/ ih_articles

Yuliana, Sudremi. 2007. Pengetahuan Sosial Ekonomi. Jakarta Bumi Aksara. 